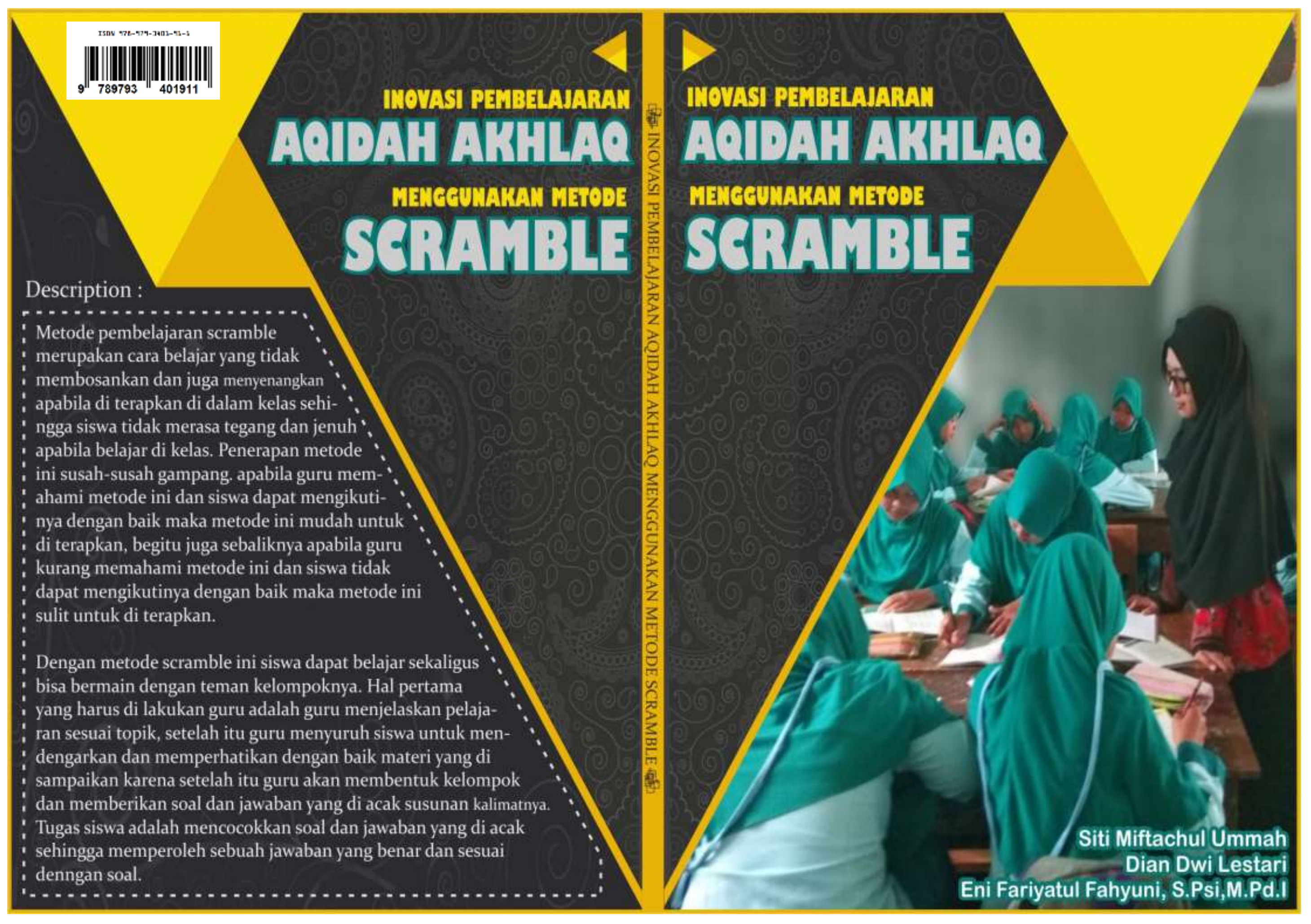




\title{
INOVASI PEMBELAJARAN AQIDAH AKHLAQ MENGGUNAKAN METODE SCRAMBLE
}

\section{Penulis}

\section{Siti Miftachul Ummah}

Dian Dwi Lestari

Eni Fariyatul Fahyuni, S.Psi., M.Pd.I

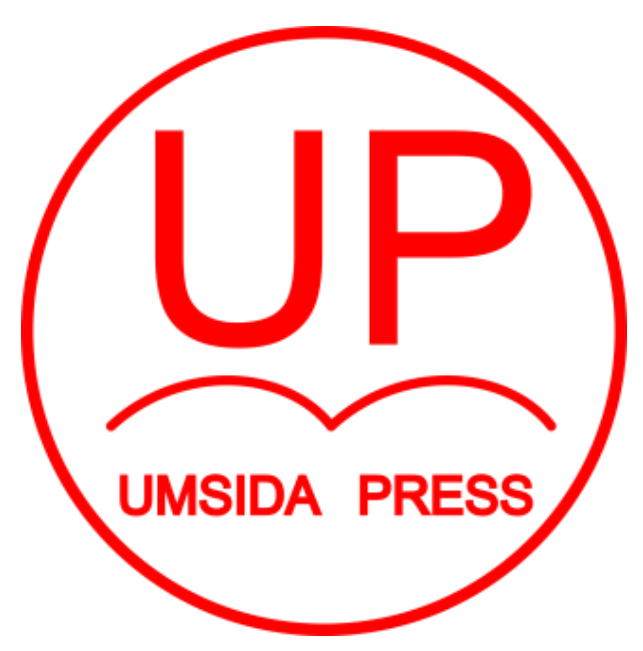

\author{
Diterbitkan oleh \\ UMSIDA PRESS \\ Jl. Mojopahit 666 B Sidoarjo \\ ISBN: $\mathrm{xxxxxxxx}$ \\ Copyright(C)2018. \\ Authors \\ All rights reserved
}


INOVASI PEMBELAJARAN AQIDAH AKHLAQ MENGGUNAKAN

METODE SCRAMBLE

Penulis :

Siti Miftachul Ummah

Dian Dwi Lestari

Eni Fariyatul Fahyuni, S.Psi., M.Pd.I

ISBN :

$\operatorname{Xxxx} \operatorname{xxxx}$

\section{Editor :}

M. Tanzil Multazam

\section{Copy Editor :}

Fika Megawati, S.Pd., M.Pd.

Design Sampul dan Tata Letak :

Ahmad Falahi

\section{Penerbit :}

UMSIDA Press

\section{Redaksi :}

Universitas Muhammadiyah Sidoarjo

J1. Mojopahit No 666B

Sidoarjo, Jawa TImur

Cetakan pertama, Februari xxxx

(C) Hak cipta dilindungi undang-undang

Dilarang memperbanyak karya tulis ini dengan suatu apapun tanpa ijin tertulis dari penerbit. 


\section{KATA PENGANTAR}

Puji syukur kami panjatkan kehadirat Tuhan Yang Maha Esa. Berkat limpahan karunia-Nya, kami dapat menyelesaikan penulisan buku Inovasi Pembelajaran Aqidah Akhlaq Menggunakan Metode Scramble. Dalam penyusunanbuku ini penulis telah berusaha semaksimal mungkin menghasilkan karya edukatif sesuai dengan kemampuan penulis. Namun sebagai manusia biasa, penulis tidak luput dari kesalahan dan kekhilafan baik dari segi tekhnik penulisan maupun tata bahasa.

Inovasi Pembelajaran Aqidah Akhlaq Menggunakan Metode Scramble ini dibuat sedemikian rupa semata-mata untuk mengembangkan minat belajar peserta didik dalam kelas dan pendidik lebih kreatif dan inovatif dalam mengajar peserta didiknya. Penulis menyampaikan ucapan terima kasih kepada semua pihak yang terlibat, sehingga kami bisa menyelesaikan buku Inovasi Pembelajaran Aqidah Akhlaq Menggunakan Metode Scramble ini .

Demikian semoga karya tulis ini dapat bermanfaat bagi penulis khususnya dan para pembaca pada umumnya.

Sidoarjo, 10 Februari 2018

Penulis 


\section{DAFTAR ISI}

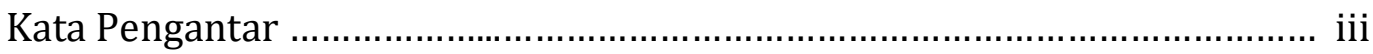

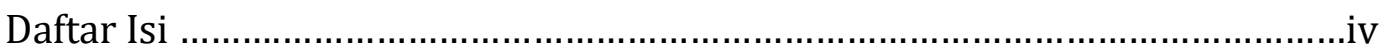

\section{BAB I HAKEKAT PEMBELAJARAN}

A. Komponen dan Faktor-Faktor Pembelajaran ............................... 1

B. Prinsip-Prinsip Pembelajaran ..............................................13

C. $\quad$ Fungsi, Tujuan, dan Manfaat Pembelajaran …............................16

D. Evaluasi Pembelajaran …........................................................ 19

\section{BAB II KARAKTERISTIK PESERTA DIDIK}

A. Karakteristik Peserta Didik ................................................... 21

B. Jenis-Jenis Perkembangan Peserta Didik ............................... 22

C. Sistem Pengelolaan Peserta Didik ......................................... 24

\section{BAB III AKTIVITAS BELAJAR}

A. Makna Belajar ........................................................................ 26

B. Jenis-Jenis Aktivitas Belajar ...............................................28

C. Kesimpulan Aktivitas Belajar ................................................ 29

\section{BAB IV KONSEP PEMBELAJARAN DENGAN METODE SCRAMBLE}

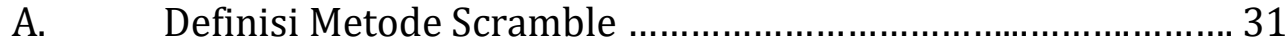

B. Macam-Macam Scramble ....................................................... 32

C. Kelemahan dan Kelebihan Metode Scramble ........................... 33

\section{BAB V PEMBELAJARAN AKIDAH AKHLAK}

A. Karakteristik Pembelajaran Akidah Akhlak ........................... 35

B. Karakteristik Pengajaran Pendidik .......................................... 36

C. $\quad$ Materi Akidah Akhlak Kelas VII ................................................ 38

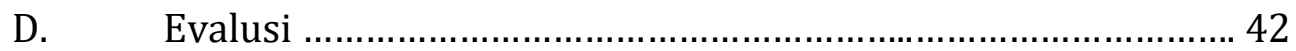




\section{BAB VI PENGEMBANGAN METODE SCRAMBLE}

A. Penerapan Pembelajaran .................................................... 46

B. Langkah-Langkah Pengajaran ........................................... 47

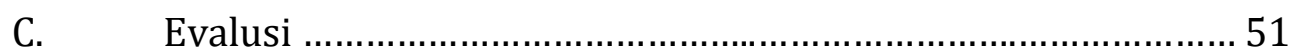

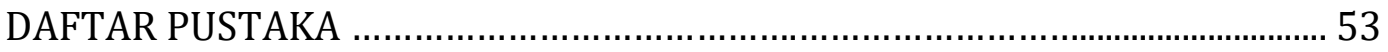

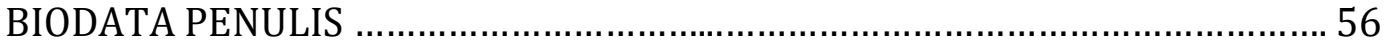




\section{BAB I}

\section{HAKEKAT PEMBELAJARAN}

Menurut Darsono (2000) pembelajaran adalah suatu cara atau proses untuk menjadikan orang menjadi belajar.Pada intinya Pembelajaran adalah proses interaksi antara peserta didik dengan lingkungan yang ada disekitar peserta didik, sehingga terjadi sebuah perubahan perilaku kearah yang lebih baik. Dan tugas pendidik adalah untuk mengkoordinasikan lingkungan agar terjadi perubahan perilaku bagi peserta didik. Pembelajaran juga dapat diartikan sebagai usaha agar peserta didik dapat belajar sesuai dengan kebutuhan dan minatnya. Disini pendidik berperan sebagai fasilitator yang menyediakan fasilitas dan menciptakan situasi yang mendukung peningkatan kemampuan belajar peserta didik.

\section{A. Komponen Pembelajaran dan Faktor-Faktor Pembelajaran}

Ada beberapa komponen-komponen dalam pembelajaran

\section{Tujuan Pembelajaran}

Hermawan,dkk (2008) Tujuan pembelajaran merupakan rumusan perilaku yang telah ditetapkan sebelumnya agar tampak pada diri peserta didik sebagai akibat dari perbuatan belajar yang telah dilakukan. Dengan tujuan yang jelas akan memberi petunjuk yang jelas terhadap pemilihan materi/bahan ajar, strategi, media, dan evaluasi. Berkaitan dengan adanya tujuan di dalam proses pembelajaran terjadi pertentangan dari beberapa pendapat tentang tujuan pembelajaran, ada sebagian ahli menyatakan tujuan pembelajaran merupakan proses dan sebagian menyatakan tujuan haruslah menggambarkan hasil belajar bukan prosesnya. dari beberapa pertentangan para ahli pendapat bahwa tujuan sebagai proses atau tidak, tujuan pembelajaran tidak dapat melepaskan diri dari tuntunan-tuntunan dan kebutuhan masyarakat, serta harus didasari dengan falsafah dan ideologi suatu negara. Hal ini bisa dimengerti sebab upaya pendidikan itu sendiri merupakan subsistem dalam sistem masyarakat dan negara sehingga kekuatan-kekuatan sosial, politik, budaya, Ekonomi sangatlah berperan dalam penentuan tujuan pembelajaran terutama tujuan pendidikan yang sifatnya lebih umum.

\section{Pendidik}


Winataputra (2007) Menurut pasal 1 butir 6 UU Nomor 20 Tahun 2003 tentang Sisdiknas, Pendidik adalah tenaga kependidikan yang berkualifikasi sebagai pendidik, dosen, konselor, pamong belajar, widyaswara, tutor, instruktur, fasilitator, dan istilah lainnya yang sesuai dengan kekhususannya yang juga berperan dalam pendidikan.Pendidik menempati posisi kunci dan strategis dalam menciptakan suasana belajar yang kondusif dan menyenangkan untuk mengarahkan peserta didik agar dapat mencapai tujuan secara optimal. Pembelajaran pada haikatnya adalah proses sebab-akibat. Pendidik sebagai seorang pengajar merupakan penyebab utama terjadinya proses pembelajaran peserta didik, meskipun tidak semuanya belajar peserta didik merupakan akibat pendidik yang mengajar. Oleh sebab itu, pendidik sebagai figur harus mampu untuk menetapkan strategi pembelajaran yang tepat sehingga dapat mendorong terjadinya perbuatan belajar peserta didik yang aktif, produktif, dan efesien. Pendidik hendaknya dalam mengajar harus memperhatikanatau mempersiapkan tingkat kematangan, dan cara belajar peserta didik.menurut Kiranawati, wijianta Peran Pendidik dalam proses belajar mengajar :
a. memperhatikan dan bersikap positif
b. mempersiapkan baik isi materi pelajaran maupun praktek pembelajarannya
c. memiliki ekspektasi yang tinggi terhadap peserta didiknya
d. memiliki sensitivitas dan sadar akan adanya hubungan antara pendidik, peserta didik, serta tugas masing-masing
e. konsisten dan memberikan umpan balik positif kepada peserta didik.

\section{Peserta didik}

Peserta didik adalah semua individu yang menjadi audiens dalam suatu lingkup pembelajaran. Biasanya penyebutan peserta didik ini mengikuti skup/ruang lingkup dimana pembelajaran dilaksanakan, diantaranya : peserta didik untuk jenjang pendidikan dasar dan menengah, mahapeserta didik untuk jenjang pendidikan tinggi, dan peserta pelatihan untuk diklat. Peserta didik adalah masukan mentah (raw input) dalam sebuah proses pembelajaran yang harus dithreat agar output dan outcomesnya sesuai dengan yang dicanangkan institusi (khususnya) dan dunia pendidikan Indonesia pada umumnya. Menurut Udin S. Winataputra (2007) Pasal 1 butir 4 UU Nomor 20 tahun 2003 tentang Sisdiknas, peserta didik adalah anggota masyarakat yang berusaha mengembangkan potensi diri melalui proses pembelajaran yang trsedia pada jalur, jenjang dan pendidikan tertentu. Peserta didik atau peserta didik merupakan subyek utama dalam pembelajaran dalam usaha 
pencapaian tujuan pembelajaran yang telah dibuat sebagai acuan kegiatan belajarmengajar.

Menurut Kiranawati (2009) peran peserta didik dalam pembelajaran, antara lain:

a. tertarik pada topik yang sedang dibahas.

b. dapat melihat relevansi topik yang sedang dibahas.

c. merasa aman dalam lingkungan sekolah.

d. terlibat dalam pengambilan keputusan belajarnya.

e. memiliki motivasi dan melihat hubungan antara pendekatan pembelajaran yang digunakan dengan pengalaman belajar yang akan dicapai.

\section{Kegiatan Pembelajaran}

Kegiatan Pembelajaran pada dasarnya mengacu pada pendekatan mengajar, metode, materi, media.

a) Pendekatan Mengajar

Winaputra (2007) menyatakan pendekatan pembelajaran yang diartikan sebagai titik tolak atau sudut pandang kita terhadap proses pembelajaran, yang bertujuan tentang pandangan terjadinya suatu proses yang sifatnya masih sangat umum, di dalamnya mewadahi, menginsiprasi, menguatkan, dan melestarikan metode pembelajaran dengan mencakup teori tertentu. Dari pendekatan pembelajaran yang telah ditetapkan selanjutnya diturunkan ke dalam strategi pembelajaran.Tinggi rendahnya aktivitas belajar peserta didik banyak dipengaruhi oleh strategi atau pendekatan mengajar yang digunakan. Banyak pendapat mengenai berbagai pendekatan yang dapat digunakan dalam penyampaian materi/bahan ajar. Ada dua tipe pendekatan mengajar yaitu:

1) Pendekatan berorientasi pada pendidik (teacher centered), Tipe Otokratis adalah Pendekatan ini biasa disebut sebagai model ekspositori atau model Informasi karena pendidik lebih dominan.

2) Pendekatan berorientasi pada peserta didik (student centered), Tipe demokratis adalah Pendekatan ini biasa disebut model Inquiry atau Problem solving karena kegiatan pembelajaran lebih berpusat pada peserta didik dan peserta didik lebih aktif dalam kegiatan belajar-mengajar.

3) Pemilihan strategi atau pendekatan yang dipilih oleh pendidik disesuaikan dengan mempertimbangkan hakikat tujuan, materi/bahan ajar, dan kesesuaian dengan tingkat perkembangan peserta didik. 


\section{Metode}

Menurut Haryanto (2009) Metode adalah "a way in achieving something". Metode pembelajaran dapat diartikan sebagai cara yang digunakan untuk mengimplementasikan rencana yang sudah disusun dalam bentuk kegiatan nyata dan praktis untuk mencapai tujuan pembelajaran. Jadi metode pembelajaran adalah cara dalam menyajikan (menguraikan materi, memberi contoh dan memberi latihan) isi pelajaran kepada peserta didik untuk mencapai tujuan tertentu. Tidak setiap metode pembelajaran sesuai untuk digunakan dalam mencapai tujuan pembelajaran tertentu. Oleh karena itu sebagai seorang pendidik haruslah mampu memilih metode yang sesuai dengan tujuan yang ingin dicapai. Ada berbagai metode pembelajaran, yaitu metode diskusi, metode ceramah, metode demonstrasi, metode studi mandiri, metode simulasi, metode latihan dengan teman, metode studi kasus, metode proyek, metode praktikum. Dalam kegiatan pembelajaran pendidik dapat menggunakan lebih dari satu metode maksudnya dapat digunakan variasi metode dalam pembelajaran.

\section{Evaluasi}

Komponen evaluasi ditujukan untuk menilai pencapaian tujuan yang telah ditentukan. Hasil dari kegiatan evaluasi dapat digunakan sebagai umpan balik (feedback) untuk memperbaikan kegiatan pembelajaran yang berkaitan dengan materi yang akan digunakan, pemilihan media, pendekatan dalam pengajaran, dan metode dalam pembelajaran. Dalam Permen No. 41 tahun 2007 tentang Standar proses dinyatakan bahwa evaluasi proses pembelajaran dilakukan untuk menentukan kualitas pembelajaran secara keseluruhan mencakup tahap perencanaan poses pembelajaran, pelaksanaan proses pembelajaran, dan penilaian hasil pembelajaran. Evaluasi dalam proses kegiatan pembelajaran diselenggarakan dengan cara:

a) Membandingkan poses pembelajaran yang dilaksanakan pendidik dengan standar proses.

b) Mengidentifikasi kinerja pendidik dalam proses pembelajaran sesuai dengan kompetensi pendidik 
Sesungguhnya, dalam konteks penilaian ada beberapa istilah yang digunakan, yakni pengukuran, assessment dan evaluasi.

1) Pengukuran atau measurement merupakan suatu proses atau kegiatan untuk menentukan kuantitas sesuatu yang bersifat numerik. Pengukuran lebih bersifat kuantitatif, bahkan merupakan instrumen untuk melakukan penilaian. Pengukuran ini, antara lain adalahsebagai berikut:
a. tujuan pengukuran
b. ada objek ukur
c. alat ukur
d. proses pengukuran
e. hasil pengukuran kuantitatif.

2) Asesmen (assessment) adalah kegiatan mengukur dan mengadakan estimasi terhadap hasil pengukuran atau membanding-bandingkan dan tidak sampai ke taraf pengambilan keputusan

3) Evaluasi secara etimologi berasal dari bahasa Inggeris evaluation yang bertarti value yang secara secara harfiah dapat diartikan sebagai penilaian. Namun dari sisi terminologis ada beberapa definisi yang dapat dikemukakan yakni:

a. Suatu proses sistematik untuk mengetahui tingkat keberhasilan sesuatu.

b. Kegiatan untuk menilai sesuatu secara terencana, sistematik dan terarah berdasarkan atas tujuan yang jelas.

c. Proses penentuan nilai berdasarkan data kuantitatif hasilpengukuran untuk keperluan pengambilan keputusan.

Berdasarkan pada berbagai batasan tiga jenis penilaian di atas, maka dapat diketahui bahwa perbedaan antara evaluasi dengan pengukuran adalah dalam hal jawaban terhadap pertanyaan "what value" untuk evaluasi dan "how much" untuk pengukuran (Mustikasari, 2009). Adapun asesmen berada di antara kegiatan pengukuran dan evaluasi. Artinya bahwa sebelum melakukan asesmen ataupun evaluasi lebih dahulu dilakukan pengukuran. Sekalipun makna dari ketiga istilah (measurement, assessment, evaluation) secara teoretik definisinya berbeda, namun dalam kegiatan pembelajaran terkadang sulit untuk membedakan dan memisahkan batasan antara ketiganya, dan evaluasi pada umumnya diawali dengan kegiatan pengukuran (measurement) serta pembandingan (assessment). Adapun langkahlangkah pokok dalam penilaian secara umum terdiri dari:
a. Perencanaan
b. pengumpulan data
c. verifikasi data
d. analisis data, dan interpretasi data. 


\section{Faktor-Faktor Pembelajaran}

faktor-faktor yang memengaruhi hasil belajarpeserta didik dapat dibedakan menjadi dua kategori, yaitu faktor internal dan faktor eksternal Kedua faktor tersebut saling memengaruhi dalam proses belajar peserta didik sehingga faktorfaktor tersebut sangat berpengaruh untuk menentukan kualitas hasil belajar peserta didik atau setiap individu.

a) Faktor Internal

Faktor internal adalah faktor-faktor yang berasal dari dalam diri individu dan dapat memengaruhi hasil belajar individu. Faktor-faktor internal ini meliputi faktor fisiologis dan psikologis.

\section{Faktor fisiologis}

Faktor-faktor fisiologis adalah faktor-faktor yang berhubungan dengan kondisi fisik setiap individu. Faktor-faktor ini dibedakan menjadi dua macam. Pertama, keadaan tonus jasmani, Keadaan tonus jasmani pada umumnya sangat memengaruhi aktivitas belajar seseorang. Kondisi fisik yang sehat dan bugar akan memberikan pengaruh yang positif terhadap kegiatan belajar individu. Sebalikrtya, kondisi fisik yang lemah atau sakit akan menghambat tercapainya hasil belajar peserta didik. Oleh karena keadaan tonus jasmani sangat memengaruhi proses belajar, maka perlu ada usaha untuk menjaga kesehatan jasmani. Cara untuk menjaga kesehatan Jasmani antara lain adalah:

a. menjaga pola makan yang sehat dengan lebih memerhatikan nutrisi yang masuk ke dalam tubuh, karena kekurangan gizi atau nutrisi akan mengakibatkan tubuh cepat lelah, lesu, dan mengantuk, sehingga tidak ada semangat untuk belajar.

b. rajin berolahraga secara teratur

c. istirahat yang cukup

d. menjaga kebersihan dan kerapian

e. melakukan konsultasi rutin dengan dokter

Dari kedua fungsi jasmani/fisiologis, Selama proses belajar berlangsung, peran fungsi fisiologi pada tubuh manusia sangat mempengaruhi hasil belajar peserta didik, terutama pancaindra. Pancaindra yang berfungsi dengan baik akan mempermudah aktivitas belajar peserta didik dengan baik pula. Dalam proses belajar, pancaindra merupakan pintu masuk bagi segala informasi yang diterima dan ditangkap oleh manusia, sehingga manusia dapat mengenal dunia luar. Pancaindra sangatlah berpengarug karena pancaindra memiliki peran yang besar dalam aktivitas belajar peserta didik adalah mata dan telinga. Oleh karena itu, baik 
pendidik maupun peserta didik perlu menjaga pancaindra dengan baik, dengan menyediakan sarana belajar yang bisa memenuhi persyaratan, memeriksakan kesehatan fungsi mata dan telinga, mengkonsumsi makanan yang bergizi, dan lain sebagainya (Dimyati, 2006).

2. Faktor psikologis

Faktor-faktor psikologis adalah keadaan psikologis seseorang yang dapat memengaruhi proses belajar. Beberapa faktor psikologis yang utama memengaruhi proses belajar adalah kecerdasan peserta didik, motivasi, minat, sikap, dan bakat.

a. Kecerdasan/inteligensi peserta didik

Pada umumnya kecerdasan diartikan sebagai kemampuan psiko-fisik dalam reaksi rangsangan diri setiap individu atau menyesuaikan diri dengan lingkungan melalui cara yang baik dan benar. Dengan kecerdasan bukan hanya berkaitan dengan kualitas otak saja, tetapi juga organ-organ tubuh yang lain. Namun bila dikaitkan dengan kecerdasan, tentunya otak merupakan organ yang paling penting dibandingkan organ yang lain, karena fungsi otak itu sendiri sebagai pengendali tertinggi dari setiap inidvidu itu sendiri. Sangatlah penting dalam proses belajar peserta didik, karena itu menenentukan kualitas belajar peserta didik. Semakin tinggi tingkat inteligensi seorang individu, semakin besar peluang individu tersebut meraih kesuksesan dalam belajar. Sebaliknya, semakin rendah tingkat inteligensi individu, semakin sulit individu itu mencapai kesuksesan dalam belajar. Oleh karena itu, perlu adanya bimbingan belajar secara khusus seperti bimbingandari orang lain, yaitu pendidik, orangtua, dan lain sebagainya. Sebagai faktor psikologis yang penting dalam mencapai kesuksesan belajar, maka pengetahuan dan pemahaman tentang kecerdasan perlu dimiliki oleh setiap calon pendidik atau pendidik profesional, sehingga mereka dapat memahami tingkat kecerdasan peserta didiknya. Pemahaman tentang tingkat kecerdasan peserta didik juga dapat di peroleh oleh orang orang tua dan pendidik atau pihak-pihak yang yang berkepentingan melalui konsultasi dengan psikolog atau psikiater untuk membantu meningkatkan kecerdasan peserta didik. Sehingga dapat lebbih memahami atau dapat diketahui abak didik berada pada tingkat kecerdasan yang mana, amat superior, superior, rata-rata, atau mungkin lemag mental. Kecerdasan seseorang merupakan hal sangat berharga dan penting untuk memprediksi kemampuan belajar peserta didik. Pemahaman terhadap tingkat kecerdasan peserta didik atau peserta didik akan sangat membantu untuk mengarahkan dan memberikan bantuan yang akan diberikan peserta didik.

a. Motivasi 
Motivasi adalah salah satu faktor yang mempengaruhi keefektifan dalam kegiatan belajar peserta didik, motivasilah yang mendorong agar peserta didik dapat melakukan kegiatan belajar lebih bersunguh-sungguh." Para ahli psikologi mendefinisikan motivasi sebagai proses di dalam diri individu yang aktif, mendorong, memberikan arah, dan menjaga perilaku setiap saat (Slavin, 1994). Motivasi juga diartikan sebagai pengaruh kebutuhan-kebutuhan dan keinginan terhadap intensitas dan arah perilaku seseorang." Motovasi dibedakan menjadi dua yaitu:

1) Motivasi intrinsik dan motivasi ekstrinsik, motivasi instrinsik adalah motivasi yang berasal dari dalam diri individu dan memberikan dorongan untuk melakukan sesuatu. Contohnya seperti seorang peserta didik yang gemar membaca, peserta didik terebut tidak perlu dipaksa untuk membaca atau disuruh-suruh karena memebaca bukan hanya sebagai aktivitas kesenangannya tetapi membaca bisa jadi menjadi kebutuhannya dalam proses belajar.

2) Motivasi instrinsik motivasi atau faktor-faktor dari luar tetapi memberi pengaruh terhadap kemauan untuk belajar diluar yang timbul dan berrfungsi karena adanya pengaruh dari luar. Contonya seperti seorang peserta didik belajar kerana ia tahu besok aka nada ulangan dengan harapan peserta didik tersebut mendapatkan nilai yang baik, sehingga peserta didik tersebut akan dipuji oleh pendidik atau temannya.

b. Minat

Secara sederhana, minat (interest) berarti kecederungan dan kegairahan yang tinggi atau keinginan yang besar terhadap sesuatu. Menurut Reber (Syah, 2003), minat bukanlah istilah yang populer dalam psikologi disebabkan ketergantungannya terhadap berbagai faktor internal lainnya, seperti pemusatan perhatian, keingintahuan, motivasi, dan kebutuhan. Minat sama halnya dengan kecerdasan dan motivasi yang memberi pengaruh terhadap aktivitas belajar peserta didik. Karena jika seorang peserta didik tidak memiliki semnagat atau kemauan untuk belajar mak ia akan malas dan tidak beremangat bahkan tidak mau belajar. Oleh karena itu seorang pendidik atau pendidik lainnya perlu untuk membangkitkan minat belajar peserta didik agar tertarik dan mau mempelajari materi pelajaran yang akan dipelajarinya. Untuk membangkitkan minat belajar peserta didik tersebut banyak berbagai cara yang bisa dilakukan atau digunakan, seperti dengan membuat materi yang akan dipelajari peserta didik dibuat dengan semenarik mungkin dan tidak membosankan, baik dari bentuk buku materi, desain pembelajaran yang lebih 
membebaskan peserta didik untuk mengeksplor apa yang dipelajari, maka dalam hal ini pemilihan jurusan atau bidang studi alangkah baiknya jika jurusan atau bidang studi dipilih sendiri oleh peserta didik sesuai dengan minat yang dimiliki oleh peserta didik.

c. Sikap

Dalam proses belajar, sikap setiap individu dapat mempengaruhi keberhasilan dalam proses belajarnya. Sikap adalah kecenderungan untuk mereaksi atau merespon dengan cara yang relative tetap terhadap objek, orang, peristiwa dan sebagainya baik secara positif maupun negatif (Muhibbinsyah, 2003). Sikap peserta didik dalam proses belajar dapat dipengaruhi oleh perasaan yang senang dan tidak senang pada seorang pendidik, pelajaran, ataupun linkungan belajar yang ada disekitarnya. Dan untuk mengantisipasi munculnya sikap yang peserta didik yang negatif dalam proses belajar, pendidik sebaiknya berusaha untuk menjadi pendidik yang lebih professional dan lebih bertanggung jawab terhadap profesionalitas, seorang pendidik akan memberikan yang terbaik bagi peserta didiknya untuk berusaha mengembangkan kepribadian sebsagai seorang pendidik yang empatik, sabar, dan memberikan pengajaran terhadap anak didiknya dengan tulus, Berusaha untuk memberikan atau menyajikan pelajaran yang dimampunya dengan bbaik dan dengan cara yang menarik agar peserta didik tidak bosan pada saat proses pembelajaran, meyakinkan peserta didik bahwa bidang studi yang di pelajarinya bisa bermanfaat bagi diri peserta didik (Sumadi, 2010).

d. Bakat

Bakat psikologis lain yang mepengaruhi proses belajar adalah bakat. Secara umum, bakat (aptitude) dideinisikan sebagai kemampuan potensial yang dimiliki seseorang untuk mencapai keberhasilan pada masa yang akan datang (Muhibbinyah, 2003). Berkaitan dengan belajar, Slavin (1994) mendefinisikan bakat sebagai kemampuan umum yang dimiliki seorang peserta didik untuk belajar. Dengan demikian bakat adalah kemapuan seseorang yang ada pada diri masingmasing dan menjadi komponen yang diperlukan dalam proses belajar seseorang. Apabila bakat yang dimiliki seseorang sesuai dengan bidang atau materi yang dipelajarinya, maka bakat tersebut akan lebih memudahkan peserta didik untuk lebih mendukung proses belajarnya sehingga kemungkinan besar ia akan berhasil. pada dasarnya setiap orang mempunyai bakat atau potensi dari dalam diri mereka sendiri untuk mrncapai sebuah prestasi belajar sesuai dengan kemampuannya masing-masing. karena itu bakat diartikan sebagai kemampuan dasar individu untuk melakukan tugas tertentu tanpa adanya ketergantungan upaya pendidikan dan latihan tertentu. Individu yang memiliki bakat tertentu, akan lebih mudah untuk 
menyerap segala informasi yang berhubungan dengan bakat yang dimiliki masingmasing individu. Misalnya, peserta didik mempunyai bakat dakam bidang bahasa maka ia akan lebih muda mempelajari bahasa-bahasa lain selain bahasa yang digunakan sehari-hari.

\section{e. Rasa Percaya Diri Peserta didik}

Rasa percaya dii timbul dari keinginan mewujudkan diri untuk melakukan tindakan dan bisa berhasil dalam melakukan tindakan tersebut. Dari segi perkembangan, rasa percaya diri dapat timbul berkat adanya pengakuan dari lingkungan. Didalam proses belajar diketahui bahwa untuk berprestasi merupakan tahap pembuktian "perwujudan diri” yang diakui oleh pendidik dan rekan sesame peserta didik. Maka makin sering seorang peserta didik menyelesaikan tugas, maka ia semakin memperoleh pengakuan umum, dan selanjutnya timbul rasa percaya diri yang semakin kuat pada diri peserta didik. Begitupun sebaliknya jika kegagalan yang terjadi berulangkali maka dapat menimbulkan rasa tidak percaya diri. Apabila rasa tidak percaya diri sangat kuat, maka peserta didik bisa saja akan menjadi takut untuk belajar dan mudah menyerah.

\section{f. Cita-Cita Peserta didik}

Dalam perkembangan, pada umumnya setiap anak pasti meiliki suatu citacita dalam hidup. Cita-cita merupakan motivasi instrinsik, adakalanya gambaran yang jelas tentang tokoh yang diteladani bagi peserta didik belum ada. Cita-cita sebagai motivasi instrinsik memerlukan didikan. Didikan adalah yang yang penting untuk mencapai sebuah cita-cita dan didikan dimulai sejak sekolah dasar. Di sekolah menengah didikan memiliki pencapaian cita-cita sudah semakin terarah. Didikan dan pencapaian cita-cita sebaiknya dimulai dari hal yang lebih sederhana ke yang semakin sulit.

\section{b. Faktor eksogen/eksternal}

Faktor eksternal merupakan faktor penyebab gangguan yang berasal dari luar Selain karakteristik peserta didik atau faktor-faktor endogen, faktor eksternal juga dapat mempengaruhi proses belajar peserta didik dalam hal ini, Muhibbisyah (2003) menjelaskan bahwa faktor-faktor eksternal yang mempengaruhi belajar dapat digolongkan menjadi dua golongan, yaitu:

1. Faktor-faktor sosial lingkungan

\section{a. Lingkungan Sosial}


Lingkungan sosial keluarga, lingkungan ini sangatlah mempengaruhi kegiatan belajar. Ketenangan yang ada didalam keluarga, sifat-sifat orang tua, demografi keluarga (letak rumah), pengelolaan keluarga, semua hal itu dapat berdampak terhadap aktivitas atau kegiatan belajar peserta didik. Hubungan antara anggota keluarga,orang tua, anak, kakak, atau adik yang harmonis akan membantu peserta didik untuk melakukan aktivitas belajar dengan baik dan lebih nyaman.

\section{b. Linkungan Sosial Sekolah}

Lingkungan sosial sekolah seperti pendidik, adsminitarsi, dan teman-teman sekelas dapat mempengaruhi proses belajar seorang peserta didik. Hubungan yang harmonis anatara keytiganya dapat menjadikan motivasi bagi peserta didik untuk melakukan kegiatan belajar lebih baik lagi di sekolah. Maka dari itu pendidik, orang tua, dan pendidik agar lebih memperhatikan dan lebih memahami bakat yang dimiliki oleh anaknya dan peserta didiknya, antara lain dengan mendukung kegiatan belajar yang positif, ikut mengembangkan, dan tidak memaksa anak untuk memilih jurusan atau bidang studi yang tidak sesuai dengan minat atau bakat yang diilikinya.

\section{c. Lingkungan Sosial Masyarakat}

Kondisi lingkungan masyarakat yang menjadi tempat tinggal peserta didik akan mempengaruhi proses belajar peserta didik. Lingkungan yang kumuh, banyak pengangguran dan anak yang terlantar juga dapat mempengaruhi aktivitas atau kegiatan belajar peserta didik, dan paling tidak peserta didik akan kesulitan ketika memerlukan teman belajar, diskusi, atau meminjam alat-alat belajar yang mungkin kebetulan peserta didik tersebut belum memilikinya.

2. Lingkungan non sosial, Faktor-faktor yang termasuk lingkungan non sosial adalah :

\section{a. Lingkungan Alamiah}

Seperti kondisi udara yang segar, tidak panas dan juga tidak terlalu dingin, sinar matahari yang tidak silau/kuat, atau tidak telalu lemah/gelap, suasana yang sejuk dan tenang. Lingkungan alamiah tersebut merupakan faktor-faktor yang dapat mempengaruhi aktivitas atau kegiatan belajar peserta didik. Sebaliknya, bila londisi lingkungan ala tidak mendukung maka akan menghambat proses belajar peserta didik.

\section{b. Faktor instrumental}


yaitu perangkat belajar yang digolongkan menjadi dua macam, pertma hardware seperti gedung sekolah, alat-alat belajar, fasilitas belajar, lapangan olahraga. Contohnya, letak sekolah atau tempat belajar yang memenuhi syaratsyarat seperti letak tempatnya tidak telalu berdekatan dengan kebisingan atau jalan yang ramai, lalu bangunan itu harus bisa memenuhi syarat-syarat yang telah disepakati dan ditentukan. Kedua software, seperti kurikulum sekolah, peraturanperaturan yang ada disekolah, buku panduan, dan lain sebagainya.

\section{c. Faktor materi pelajaran (yang diajarkan ke peserta didik)}

Faktor ini hendaknya disesuaikan dengan usia perkembangan peserta didik, begitu juga dengan mtode mengajar pendidik. karena ituagar pendidik bisa memberikan kontribusi yang lebih positif terhadap aktivitas belajar peserta didik maka pendidik harus bisa menguasai berbagai macam materi atau metode mengajar yang dapat diterapkan sesuai dengan kondisi peserta didik.

\section{d. Faktor Pendekatan Belajar}

Pendekatan belajar dapat dipahami sebagai suatu cara atau strategi yang digunakan peserta didik dalam menunjang keefektifan dan efesiensi proses pembelajaran materi tertentu. Strategi dalm hal ini dalam hal ini berarti seperangkat langkah operasional yan direkayasa sedemikian rupa untuk memecahkan masalah atau mencapai tujuan belajar tertentu (Lawson, 1991). Disamping faktor-faktor internal dan eksternal peserta didik faktor pendekatan belajar kepada peserta didik juga mempunyai pengaruh pada taraf keberhasilan dalam proses belajar tersebut. Seorang peserta didik yang sudah terbiasa mengaplikasikan pendekatan belajar didepan, misalnya peserta didik tersebut bisa mempunyai peluang untuk meraih prestasi belajar yang bermutu dari pada peserta didik yang menggunkan pedekatan belajar.

1) Bimbingan

Di dalam proses belajar anak juga memerlukan adanya bimbingan. Dengan adanya bimbingan yang diberikan kepada anak tujuannya untuk mencegah kegagalan pada anak dalam melakukan aktivitas, melainkan dengan adanya bimbingan anak bisa membawa kesuksesan dan bimbingan dapat menghindarkan kesalahan dan bisa memperbaikinya. Keefektifan bimbingan belajar ini tergantung dari macam-macam tugas dan kebutuhan dari orang yang belajar. Bimbingan yang diberikan jangan terlalu berlebihan kepada peserta didikkarena ini akan meeusak tujuan Apabila orang yang belajar telah menguasai inti tugasnya, bimbingan harus dihilangkan. Karena kalau diberikan terlalu banyak bimbingan ini akan mengakibatkan terhambatnya inisiatif, hingga tidak ada kemauan lagi untuk 
berusaha. Dan sebaliknya apabila bimbingan diberikan terlalu sedikit, maka perhatian akan hilang dan kepercayaan terhadapa diri sendiri akan menjadi lemah. Contohnya terlalu banyak bimbingan yang diberikan misalnya dalam memecahkan persoalan selalu dibimbing, maka makin lama akan makin tidak ada usaha untuk berusaha sendiri dalam menghadapi persoalan. Ia akan selalu menanati pertolongan di dalam segala hal. Motiv ini sama saja dengan apa yang sering disebut dalam bahasa Inggris "Drive"atau "need". Yaitu sesuatu dalam diri manusia yang mendorong manusia untuk berbuat menuju ke suatu tujuan. Di dalam pendidikan, motivasi ialah seni yang merangsang perhatian pada murid apabila tidak mempunyai perhatian, atau yang belum dirasakn oleh murid atau enyempurnakan perhatian yang sudah ada supaya menjadi perbuatan yang dikehendaki masyarakat. Motivasi dalam belajar menmgandung : membangkitkan dan memberi kekuatan serta memberi arah pada tingkah laku yang diinginkan.

\section{2) Ulangan}

Didalam belajar perlu adanya ulangan-ulangan. Hal ini adalah elemen vital dalam belajar. Adanya ulangan-ulangan ini dapat menunjukkan pada orang yang belajar kemajuan-kemajuan dan kelemahan-kelemahan nya. Dengan demikian orang yang belajar akan menambah usah nya untuk belajar. Penting diperhatikan tentang memberitahukan hasil ulangan, supaya anak tahu hasil nya. Dan perlu pula memperbincangkan kesalahan-kesalahan yang diperbuat, supaya kesalahan baru tidak diperbuat lagi. Dalil-dalil dalam ilmu tata bahasa akan lebih mudah dipelajari apabila dipergunakannya dalam hubungan nya dengan pemakaian praktis dalam bahas tulis maupun lisan (Mustaqim, 2003).

\section{B. Prinsip-Prinsip Pembelajaran}

Ada beberapa prinsip-prinsip pembelajaran yang harus diperhatikan

\section{Perhatian dan motivasi}

Perhatian dalam pembelajaran mempunyai peranan yang sangat penting dalam pembelajaran. Karena pada kenyataannya menunjukkan perhatian tidak mungkin terjadi pembelajaran yang baik dari pihak pendidik maupun dari pihak peserta didik. Secara psikologis, apabila sudah berkonsentrasi (memusatkan perhatian) pada sesuatu maka segala stimulus yang lainnya tidak diperlukan. Akibat dari keadaan ini kegiatan akan berjalan dengan sangat baik, bahkan lebih mudah untuk masuk kedalam ingatan. Motivasi juga mempunyai peran penting dalam kegiatan pembelajaran. Seseorang akan berhasil dalam proses belajar apabila keinginan untuk belajar itu timbul dari dirinya. Walaupun dikatakan bahwa 
motivasi dan perhatian harus sejalan. Berbeda halnya kalau perhatian yang disengaja atau sekehendak, hal ini diperlukan adanya motivasi.

\section{Keaktifan}

Mengajar adalah proses membimbing pengalaman belajar, pengalaman tersebut diperoleh jika peserta didik mempunyai keaktifan untuk bereaksi terhadap lingkungannya. Termasuk dalam proses pembelajaran peserta didik harus berusaha untuk selalu aktif. Mulai dari kegiatan fisik yang mudah diamati sampai padazz kegiatan psikis yang susah untuk diamati. Dengan demikian untuk mencapai proes belajar yang berhasil harus melalui berbagai macam aktivitas baik fisik maupun psikis. Bukan hanya sekedar menghafal rumus-rumus atau informasi tetapi belajar yang lain seperti membaca, mendengar, menulis, berlatih keterampilanketerampilan, dan sebagainya. Aktivis diatas menurut psikologi bahwa segala pengetahuan harus diperoleh melalui pengamatan dan pengalaman sendiri. Oleh karena itu dalam pembelajaran yang mengolah dan merencana adalah peserta didik dengan kemauan, kemampuan bakat, dan latar belakang masing-masing, pendidik hanya memperhatikan keaktifan peserta didik dengan menyajikan bahan pelajaran (Dimyati, 2009).

\section{Keterlibatan Langsung}

Prinsip keterlibatan langsung sangatlah penting dalam pembelajaran. Pembelajaran sebagai aktifitas belajar dan mengajar, maka peserta didik dan pendidik harus terlibat langsung dalam kegiatan pembelajaran. Edge Dale mengatakan "belajar yang baik adalah belajar melalui pengalaman langsung" pembelajaran bukan hanya sekedar duduk dalam kelas ketika pendidik sedang menjelaskan pelajaran, tetapi bagaimana peserta didik terlibat langsung dalam proses pembelajaran, karena pembelajaran yang diberikan pendidik merupakan pengalaman belajar bagi peserta didik.

\section{Pergaulan}

Prinsip pembelajaran menekankan pentingnya pergaulan, dari bebrgai terori menekankan sangatlah penting prinsip pergaulan dalam pembelajaran walaupun dengan tujuan yang berbeda. Sebab dalam pembelajaran masih sangat dibutuhkan pergaulan-pergaulan atau latihan-latihan. Hubungan stimulus dan respon akan bertambah erat kalau sering dipakai dan akan berkurang apabila sama sekali jarang untuk digunakan. Oleh karena itu perlu banyak latihan, pergaulan, dan pembiasaan. 


\section{Proses Individual}

Proses pembelajaran yang berlangsung disekolah-sekolah pada saat ini masih cenderung berlangsung secara klasikal yang artinya seorang pendidik menghadapi 30-40 peserta didik dalam satu kelas. Dan pendidik masih saja menggunakan metode yang sama kepada seluruh peserta didik dalam kegiatan pembelajaran dikelas. Bahkan pendidik memperlakukan semua peserta didiknya secra merata tanpa pendidik memperhatikan latar belakang sosial budaya, kemampuan individual dan segala perbedaan tentang individual peserta didik. Setiap peserta didik pasti memiliki cirri-ciri pembawaa yang berbeda. Ada peserta didik yang mempunyai badan tinggi kurus, gemuk pendek, ada yang cekatan, lincah, periang, ada pula yang lamban, mudah tersinggung, dan beberapa sifat-sifat individual yang berbeda. Oleh karena itu untuk memberikan bantuan kepada peserta didik agar dapat mengikuti kegiatan pembelajaran yang disajikan oleh pendidik, maka pendidik harus benar-benar bisa memahami karakter peserta didik atau ciri-ciri para peserta didik. Begitu pula pendidik juga harus mampu mengatur kegiatan pembelajaran, dimulai dari perencanaan, proses pelaksanaan sampai pada tahap terakhir yaitu tahap evaluasi, sehingga peserta didik secara keseluruhan bisa mengikuti proses kegiatan pembelajaran dengan baik tanpa perbedaan yang berarti walaupun dari latar belakang dan kemampuan yang berbeda. Perbedaan individual harus menjadi perhatian bagi pendidik untuk mempersiapkan kegiatan pembelajaran yang akan dilakukan didalam kelas. Karena perbedaan individual merupakan suatu prinsip dalam kegiatan pembelajaran yang tidak boleh dihiraukan demi keberhasilan dalam proses kegiatan pembelajaran (Rohani, 2004).

\section{Tantangan}

Tantangan menurut pernyataan Field Teory dari Kurt Lwein (Soeparlan, 2014) mengemukakan bahwa peserta didik dalam situasi belajar berada dalam suatu medan atau lapangan psikologis. Dalam situasi belajar peserta didik pasti akan menghadapi suatu tujuan dan juga akan menghadapi suatu hambatan yaitu mempelajari materi pembelajaran pasti akan menemukan motif untuk mengatasi hambatan itu yaitu dengan cara mempelajari bahan pembelajaran tersebut apabila hambatan tersebut sudah diatasi artinya bahwa tujuan pembelajaran telah tercapai maka ia akan memasuki tujuan baru.

\section{Prinsip Balikan dan Penguatan}

Prinsip belajar yang berkaitan dengan balikan dan penguatan terutama ditekankan oleh teori belajar operant conditioning dari B.F. Skinner, pada teori 
conditioning yang diberi kondisi adalah stimulusnya sedangkan pada operant conditioning yang diperkuat adalah responnya. Menurutnya peserta didik akan belajar lebih semangat apabila mengetahui dan mendapatkan hasil yang baik. Apalagi hasil yang baik merupakan balikan yang menyenangkan dan berpengaruh baik bagi usaha belajar selanjutnya (Darmawan, 2012).

\section{Fungsi, Tujuan, dan Manfaat Pembelajaran}

Fungsi dari pembelajaran adalah untuk mengembangkan seoptimal mungkin dari semua aspek pribadi peserta didik. sehingga pada perkembangan peserta didik yang berikutnyaItu dapat mencapai prestasi semaksimal mungkin sesuai dengan bakat dan kemampuannya. Secara umum funsi dari pembelajaran dibagi menjadi beberapa bagian yaitu :

\section{Fungsi Pemahaman}

Fungsi pemahaman artinya tentang diri peserta didik sendiri serta tentang lingkungan tempat tinggal peserta didik, baik dari peserta didik sendiri mauoun dari pihak-pihak yang lain yang akan membantu.

\section{Fungsi Pencegahan}

Fungsi pencegahan didefinisikan dengan memberikan upaya untuk mempengaruhi dengan cara yang positif dan lebih bijaksana. Definisi tersebut memiliki maksud bahwa perhatian terhadap lingkungan mendapat perhatian utamadan lingkungan yang baik akan memberikan pengaruh yang positif bagi individu.

\section{Fungsi Pemeliharaan}

Fungsi pemeliharaan berarti memelihara segala sesuatu dengan baik yang ada pada diri individu, hal itu baik dari pembawaan maupun hasil-hasil perkembangan yang telah dicapai selama ini. ${ }^{1}$

\section{Tujuan Pembelajaran}

Gagasan perlunya tujuan dalam pembelajaran pertama kali dikemukakan oleh B.F. Skinner pada tahun 1950. Kemudian diikuti oleh Robert Mager pada tahun 1962 yang dituangkan dalam bukunya yang berjudul preparing instruction objective. Sejak pada tahun 1970 hingga sekarang penerapannya semakin maluas hampir di seluruh lembaga pendidikan di dunia, termasuk di Indonesia. Beberapa

${ }^{1}$ Priyanto.dasar-dasar Bimbingan dan konseling. Jakarta : Rineka Cipta. 2000 
para ahli memang memberikan rumusan tujuan pembelajaran dengan pendapat yang berbeda-beda, tetapi dari semua pendapat mereka yang berbeda-beda tetap menunjuk pada esensi yang sama bahwa :

1) Tujuan pembelajaran adalah terwujudnya atau tercapainya perubahan perilaku atau kompetensi pada peserta didik-siswi setelah mereka mengikuti kegiatan pembelajaran..

2) Tujuan di rumuskan dalam bentuk penyataan atau deskripsi yang spesifik.Upaya untuk merumuskan tujuan pembelajaran dapat bermanfaat bagi pendidik maupun peserta didik dalam proses pembelajaran, Nana Syaodih Sukmadinata (2002) mengidentifikasikan empat tujuan dari pembelajaran yaitu :

a. Mempermudah dalam mengkomunikasikan maksud dari kegiatan belajar mengajar pada peserta didik, sehingga peserta didik dapat lebih mandiri dalam melakukan proses pembelajaran.

b. Memudahkan pendidik untuk memilih dan menyusun bahan pembelajaran.

c. Membatu memudahkan pendidik untuk menentukan kegiatan pembelajaran dan media pembelajaran.

d. Memudahkan pendidik untuk memberikan penilaian kepada peserta didik.

Dalam permendiknas RI No. 52 Tahun 2008 tentang standar proses disebutkan bahwa tujuan pembelajaran memberikan petunjuk atau arahan untuk memilih isi mata pelajaran, menata urutan topik-topik yang sudah ditentukan, mengalokasikan waktu, petunjuk dalam memilih alat-alat bantu pengajaran dan prosedur pengajaran, serta menyediakan ukuran (standar) untuk mengkur prestasi peserta didik.

\section{Manfaat Pembelajaran}

Menurut sardirman (2004) dalam Setiap saat dalam kehidupan pasti akan terjadi proses belajar mengajar, baik sengaja maupun tidak disengaja, disadari atau tidak disadari. Dari proses belajar megajar ini kita akan memperoleh suatu hasil pada intinya kita akan mendapatkan pengetahuan, keterampilan, dan penanaman sikap mental atau nilai-nilai.Perubahan dan kemampuan untuk berubah merupakan batasan dan makna yang terkandung dalam proses belajar. Dikarenakan kemampuan berubah karena belajarlah, maka manusia bisa berkembang lebih jauh dari pada makhluk-makhluk lainnya. Sehingga ia terbatas dari kemandegan fungsinya sebagi khalifah. Tuhan di muka bumi. Boleh jadi karena kemampuan yang berkembang melalui proses belajar itu pula manusia secara bebas dapat 
mengeksplorasi, memilih dan menetapkan keputusan-keputusan penting untuk kehidupan. Banyak sekali kalau bukan seluruhnya bentuk-bentuk perkembangan yang terdapat dalam diri manusia yang bergantung pada belajar antara lain misalnya perkembangan kecakapan berbicara. Menurut fitrahnya, setiap bayi yang normal memiliki potensi untuk cakap berbicara sepeti ayah bundanya. Namun, kecakapan berbicara sang bayi itu takan pernah terwujud dengan baik tanpa upaya belajar walaupun pross kematangan perkembangan organ-organ mulutnya telah selesai.

Belajar juga memainkan peran penting dalam mempertahankan kehidupan sekelompok umat manusia (bangsa) di tengah-tengah persaingan yang semakin ketat di antara bangsa-bangsa lainnya yang lebih dahulu maju karena belajar. Meskipun ada dampak negatif dari hasil belajar sekelompok manusia tertentu, kegiatan belajar tetap memiliki arti penting, seperti yang telah dikemukakan di atas, belajar itu berfungsi sebagi alat mempertahankan kehidupan manusia. Artinya, dengan ilmu dan tekhnologi hasil belajar kelompok manusia tertindas itu juga dapat digunakan untuk membenteng pertahanan. Selain daripada itu manfaat dari belajar kita bisa mengubah tingah laku. Jadi belajar akan membawa suatu perubahan pada individu-individu yang belajar. Perubahan tidak hanya berkaitan dengan penambahan ilmu pengetahuan, tetapi juga berbentuk kecakapan, keterampilan, sikap, pengertian, harga diri, minat, watak, penyesuaian diri. Jelasnya menyangkut segala aspek organisme dan tingkah laku pribadi seseorang. Dengan demikian, dapatlah dikatakan bahwa belajar itu sebagai rangkaian kegiatan jiwa raga, psikofisik untuk menuju ke perkembangan pribadi manusia seutuhnya, yang berarti menyangkut unsur cipta, rasa dan karsa, ranah kognitif, afektif dan psikomotorik.

Selanjutnya dalam perspektikkeagamaanpn (dalam hal ini Islam), belajar merupakan kewajiban bagi setiap orang beriman agar memperoleh ilmu pengetahuan dalam rangka meningkatkan derajat kehidupan mereka. Sebagaiman yang telah dijanjikan "Niscaya Allah akanmeninggikan beberapa derajat kepada orang-orang yang beriman dan berilmu". Ilmu dalam hal ini tentu saja tidak hanya berupa pengetahuan agama tetapi juga berupapengetahuan yang relevan dengan tuntutan kemajuan zaman. Selain itu, ilmu tersebut juga harus bermanfaat bagi kehidupan orang banyak disamping bagi kehidupan diri pemilik itu sendiri. Belajar pada dsarnya merupakan peristiwa yang bersifat individual yakni peristiwa terjadinya perubahan tingkah laku sebagi dampak dari pengalaman individu. Pengalaman dapat berupa situas belajar yang tercipta karena dirancang oleh orang lain di luar diri individu sebagai pebelajar biasa disebut proses pembelajaran (Sardiman, 2004). 


\section{Evaluasi Pembelajaran}

Evaluasi Menurut kamus Oxford Advanced Learners Dictionary of Current English AS Hornby, 186) evaluasi adalah to find out, decide the amount or value yang artinya suatu upaya untuk menentukan nilai atau jumlah. Dari kalimat itu menunjukan bahwa kegiatan evaluasi harus dilakukan secara hati-hati, bertanggung jawab, menggunakan strategi, dan dapat dipertanggungjawabkan (Arikunto, 2007).

Dalam evaluasi selalu mengandung proses. Proses evaluasi harus tepat terhadap tipe tujuan yang biasanya dinyatakan dalam bahasa perilaku. Dikarenakan tidak semua perilaku dapat dinyatakan dengan alat evaluasi yang sama, maka evaluasi menjadi salah satu hal yang sulit dan menantang yang harus disadari oleh para pendidik. 


\section{DAFTAR PUSTAKA}

A.M Sardiman. Interaksi dan Motivasi Belajar Mengajar. Jakarta: Rajawali. 2011

Ahmad Tafsir. Pendidikan Dalam Prespektif islam. Bandung: PT Rosyda Karya. 2001

Arikunto, S, dan Jabar, C. S. A. Evaluasi Program Pendidikan. Jakarta: Bumi Aksara. 2007, Cet ke-2

Atwi Suparman. Desain Instruksional. Jakarta: Universitas Terbuka. 1997, Cet ke-6

Buna'i. Perencanaan Pembelajaran PAI. Surabaya: Pena Salsabila. 2013

Darmawan, Deni. Konsep Dasar Pembelajaran. 2012

Darsono, Max, dkk. Belajar dan Pembelajaran. Semarang: IKIP Semarang Pres. 2000

Dimyanti dan Mudiono. Belajar dan Pembelajaran. Jakarta: PT Asdi Mahasatya. 2006

Endraswara, Suwardi. 30 Metode Pembelajaran Bahasa \& Sastra Jawa. Yogyakarta: Kuntul Press. 2009

Fahyuni, E., \& Fauji, I. Pengembangan Komik Akidah Akhlak Untuk Meningkatkan Minat Baca dan Prestasi Belajar Peserta didik di Sekolah Dasar. Journal Halaqa 1 (1). Juni 2017. ISSN 2503-5045 Cet Ke-1

Fahyuni, Eni Fariyatul \& Istikomah. Psikologi Belajar \& Mengajar (kunci sukses guru dalam interaksi edukatif). Sidoarjo: Nizamia Learning Center. 2016, cet ke1

Fahyuni, Eni Fariyatul. \& Bandono, Adi. Pengembangan Media Cerita Bergambar Sebagai Upaya Meningkatkan Kemampuan Membaca Siswa Sekolah Dasar. Halaqa: Jurnal Kependidikan dan KeislamanVol 14. No. 1. April 2015.75-89

Haryanto. Komponen-komponen Pembelajaran Pengertian-pendekatan-strategimetode-teknik-taktik-dan-model-pembelajaran. 28 September 2009 
Hermawan, A.H dkk. Pengembangan Kurikulum dan Pembelajaran. Jakarta: Universitas Terbuka. 2008

Ibrahim dan Darsono. Membangun Akidah dan Akhlak untuk kelas VII Madrasah Tsanawiyah. Solo: PT Tiga Serangkai Pustaka Mandiri. 2009

Kasyadi, Soeparlan dan dkk. Strategi Belajar dan Pembelajaran. Jakarta: Pustaka Mandiri. 2014

Kementrian Agama. Buku Pendidik Akidah Akhlak. Jakarta: Kementrian Agama. 2014, cet ke-1

Kiranawati. Komponen Pembelajaran. 28 September 2009

Komalasari, Kokom. Pembelajaran Kontekstual Konsep dan Aplikasi. Bandung: PT Refika Aditama. 2013

Kosim, Mohammad. Pengantar Ilmu Pendidikan. Surabaya: Pena Salsabila. 2013

Mahjuddin. Akhlak Tasawuf. Jakarta: Kalam Mulia. 2009

Muchlis Sholichin. Psikologi Belajar. Surabaya: Pena Salsabila. 2013

Mudjiono dan Dimyati. Belajar dan Pembelajaran. Jakarta: Rineka Cipta. 2009

MuhibinSyah. Psikologi belajar. Jakarta: PT Raja Grafindo Persada. 2003

Mustaqim dan Wahid, Abdul. Psikologi Pendidikan. Jakarta: PT Melton Putra. 2003

Mustikasari. Ardiani, Evaluasi-proses-pembelajaran. 28 September 2009

Nana syaodih sukmadinata. Pengembangan kurikulum: Teori dan praktek. Bandung: PT Remaja Rosdakarya. 2002

Nasution, S. Berbagai pendekatan dalam Proses Belajar Mengajar. Jakarta: PT Bumi Aksara. 1997

Priyanto. Dasar-dasar Bimbingan dan konseling. Jakarta: Rineka Cipta 2000

Richard. Psikologi Perkembangan. Universitas Negeri Jakarta. 2004

Rohani Ahma. Pengelolaan Pengajaran. Jakarta: Rineka Cipta. 2004 
Sardiman, A.M. Interaksi dan Motivasi Belajar Mengajar. Jakarta: PT Raja Grafindo Persada. 2004

Shoimin Aris. 68 Model Pembelajaran dalam kurikulum 2013. Yogyakarta: ar-ruz Media. 2014

Slameto. Belajar dan Faktor-faktor yang Mempengaruhinya. Jakarta : Rineka Cipta. 1995, Cet Ke-2

Soeparno. Media Pengajaran Bahasa. Klaten: Intan Pariwara. 1988

Suryabrata, Sumadi. Psikologi Pendidikan. Jakarta: PT Raja Grafindo Persada. 2010

Syaiful Bahri Djamarah \& Aswan Zain. Strategi Belajar Mengajar. Jakarta: Rineka Cipta. 2006

Wina Sanjaya. Strategi Pembelajaran Berorientasi Standar Proses Pendidikan. Jakarta: Kencana Prenada Media. 2011

Winataputra, Udin.S. Teori Belajar dan Pembelajaran. Jakarta: Universitas Terbuka. 2007 


\section{BIODATA PENULIS}

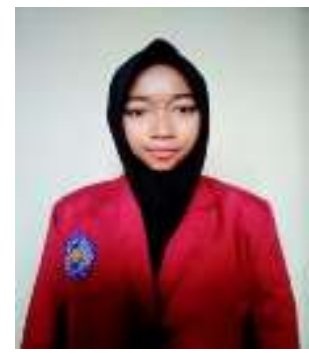

Siti Miftachul Ummah merupakan seorang mahasiswi di jurusan Pendidikan Agama Islam, Fakultas Agama Islam, Universitas Muhammadiyah Sidoarjo. Putri pertama dari pasangan Bapak Shokim dan Ibu Umi Musholiyah ini lahir di Sidoarjo, 11 Juni 1998. Latar belakang pendidikannya adalah MI Nurul Huda Sedati (2011), Mts Nurul Huda Sedati (2014), MA Nurul Huda Sedati (2017) dan saat ini penulis menempuh studi Sarjana Program Studi Pendidikan Agama Islam di Universitas Muhammadiyah Sidoarjo (UMSIDA).

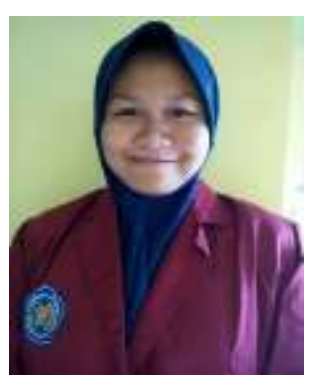

\section{BIODATA PENULIS}

Dian Dwi Lestari merupakan seorang mahasiswi di jurusan Pendidikan Agama Islam, Fakultas Agama Islam, Universitas Muhammadiyah Sidoarjo. Putri kedua dari pasangan Bapak Asmuji dan Ibu Sari Ani ini lahir di Sidoarjo, 27 November 1998. Latar belakang pendidikannya adalah SDN Sambibulu (2011), Mts Muhammadiyah 1 Taman (2014), Sma Muhammadiyah 1 Taman (2017) dan saat ini penulis menempuh studi Sarjana Program Studi Pendidikan Agama Islam di Universitas Muhammadiyah Sidoarjo (UMSIDA)

\section{BIODATA PENULIS}

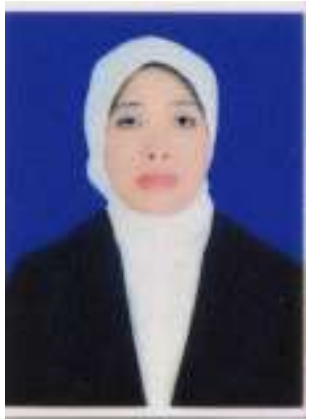

Eni Fariyatul Fahyuni merupakan dosen sekaligus pembimbing penulisan buku di Fakultas Agama Islam, Universitas Muhammadiyah Sidoarjo yang mengampu beberapa mata kuliah diantaranya: profesi keguruan, ilmu kependidikan, bimbingan dan konseling, psikologi perkembangan, psikologi belajar, dan ICT pembelajaran. Buku hasil karya yang sukses diterbitkan antara lain 1) Tahun 2016, buku Inovasi Model Pembelajaran Sesuai Kurikulum 2013; 2) Tahun 2016, buku Psikologi Belajar dan Mengajar (Kunci Sukses Guru dan Peserta Didik dalam Interaksi Edukatif); 3) Tahun 2017, buku Teknologi Informasi dan Komunikasi (Prinsip dan Aplikasi dalam Studi Pemikiran Islam), 4) tahun 2018, Kenapa Bisa Begini, Ya? Suhu dan Kalor, dan 5) Tahun 2018, buku ajar "Senangnya Bisa Bersedekah". Latar belakang pendidikannya S1 Psikologi, Universitas Islam Negeri Sunan Ampel Surabaya (2011). Pendidikan Islam Pascasarjana Universitas Muhammadiyah Sidoarjo (2013), dan saat ini penulis sedang menempuh studi Doktoral Program Studi Teknologi Pendidikan di Universitas Negeri Surabaya (UNESA). 